\title{
A Cultural Reading of a Chinese White-Collar Workplace Bestseller and its Film Adaptation: Li Ke's A Story of Lala's Promotion and Go Lala Go!
}

\author{
Shenshen Cai, University of Melbourne
}

According to Sheldon Hsiao-peng Lu, in the 1990s 'the mushrooming culture industry - TV serials, soap operas, pop music, and bestsellers - were easily accessible and had great appeal to the vast population of China' (1996: 152). This continued into the new millennium, when China's capitalist economy matured and the popular culture industry gradually dominated the contemporary Chinese cultural landscape. In 2007, Li Ke's white-collar workplace novel Du Lala Shengzhiji (henceforth A Story of Lala's Promotion) became a bestseller among Chinese white-collar workers in foreign-owned (Western) companies. ${ }^{1}$ The novel also struck a chord with the Chinese middle class. Although foreign-owned and -operated enterprises and associated company culture are not new economic or cultural phenomena in China, detailed examinations of the lives of Chinese workers in these organisations were not widely available in textual or visual creative works until relatively recently. Li Ke's novel thus represented a breakthrough cultural text. Since its release in 2007, A Story of Lala's Promotion has ranked at the top of the bestseller lists for 88 weeks on Dangdang Web-Dangdang Web being one of the most popular on-line shopping websites in China. In 2008 its sequel As Time Goes By (Nianhua Sishui) was published and in 2010, another sequel, In This Struggling Year (Wo Zai Zhe Zhandou de Yinian Li), was released. Also in 2010, the film adaptation of A Story of Lala's Promotion, Du Lala Shengzhiji (Dir. Xu Jinglei, henceforth Go Lala

\footnotetext{
${ }^{1}$ The author Li Ke has worked in various roles including as a salesperson and HR officer for world top500 companies for ten years. As she indicates in the prologue of the book, she wants to share her experiences and provide her readers with information that is easy to understand and remember, practical, interesting and widely applicable. In other words, she hopes that $A$ Story of Lala's Promotion, despite being a novel, will also become a classic career textbook for those who work in foreign enterprises.
} 
Go!) by the well-known Beijing-based actor-writer-director, Xu Jinglei, was shown in cinemas. A television-drama adaptation based on the same novel also aired in that year. The total box-office revenue of the film reached 100 million RMB (some USD16 million) within days of its release, while the television show also enjoyed huge popularity.

A Story of Lala's Promotion describes the business and cultural landscape of a foreignowned company operating in a Chinese social milieu, with particular attention paid to operational mechanisms, company culture, human resource (HR) management and interpersonal relations. Focusing on a group of core characters-Du Lala (HR and administration manager), David (major clients department sales director), Lester (HR director) and Howard (CEO of the Chinese company) - the novel revolves around office politics, Western company culture, the lifestyle of white-collar workers, middle-class aesthetics and the 'shengnu' (shelved ladies) phenomenon. 'Shelved ladies' is a new term in China that denotes single women in their late twenties or early thirties, whose employment and income are high enough to provide them with economic independence and social status (Cao 2010: 56).

To decipher the embedded cultural codes of A Story of Lala's Promotion and Go Lala Go! in this paper I have conducted a comparative analysis of three interconnected themes of the novel and the film adaptation. First, I identify the influence of Western company culture and workplace rules on Chinese white-collar workers, under the rubric of an overwhelming economic globalisation, in order to explain how the acculturating process of Western culture is having an impact on its Chinese counterpart. Then I argue that given the opportunities provided by Western enterprises, intelligent and diligent Chinese women familiarise themselves with Western workplace strategies, management systems and corporate culture, which thus ensures their competitive capacities in relation to their male counterparts at work. Consequently, many women reach high management levels, whereas China's workplace culture discriminates against female workers within the context of a developing economy.

Second, I examine the achievements of female Chinese white-collar staff in foreign enterprises in terms of their economic independence and self-confidence, and the social respect with which they are held. These achievements also shed some light on the intense social debate around the 'shelved ladies' phenomenon in contemporary China. 
From a feminist perspective, Du Lala's image and struggle is identifiable with the 'shelved ladies' phenomenon, and her experiences also serve as a metaphor of female individuality and liberation, echoing current trends identified in Chinese feminist studies.

Third, I shift my focus to the film adaptation of the novel, which highlights the whitecollar female worker's lifestyle, including the pursuit of luxury goods and well-known Western brands, a phenomenon not dealt with in the original novel depiction. This particular feature of globalising processes at work in China occurs within the domain of consumption, and further consolidates the Westernising trend in and impact of global economic and cultural contacts, particularly in relation to the growing economic independence enjoyed by Chinese middle-class white-collar women. Finally, I argue that the film adaptation of the novel also highlights the Chinese pursuit of a middleclass identity and aesthetic as typified by the lifestyle of the white-collar social strata, itself a mirror to the overwhelming consumerism of post-socialist China.

\section{Westernisation and globalisation reflected in the workplace}

Since China opened to the outside world at the end of the 1970s, and as the world economy has globalised, joint ventures and foreign-invested enterprises-mainly Western companies from North America and Europe- have become an indispensable part of China's market economy. The engagement of these joint ventures and foreignoperated companies with the Chinese economy is not simply a process of internationalisation - 'a mere quantitative increase in the contacts and flows across nation-state boundaries or an increasing outward-orientation of the nation-state' (Albert cited in Loubere 2010: 72). Instead, that engagement represents how globalisation 'influences and structures processes of economic production and exchange, political authority, the formation of individual and collective identities, or cultural frames of reference' (Albert cited in Loubere 2010: 72). This differentiation between internationalisation and globalisation helps us understand the function, philosophy and politics of joint ventures and foreign-invested enterprises, which represent not only an expansion of the Western capitalist economic form, but also a corporate cultural invasion of the receiving countries. According to $\mathrm{Yu}$, 'Economic globalization not only has greatly changed production, consumption, and exchange, but it has also altered modes of thinking and behaviour, and has had a major impact on national cultures' 
(2008: 157). China's export-oriented economic model compels foreign-invested companies to play a critical role in maintaining China's economic prosperity: Western work modes, office politics and lifestyles, which are part of corporate culture, have an immense influence on the Chinese workers employed by and in these enterprises.

Some scholars, however, have offered different observations regarding the global corporate culture as manifested in China. This culture indicates that traditional Chinese values, such as an emphasis on the maintenance of harmonious relations between colleagues, preservation of the collective, agreement to prearranged social structures and power hierarchy, holism, contextualism, saving face, and reciprocity of relationships and guanxi (ties and connections), continue to influence Chinese staff working in foreign-run enterprises, particularly when settling conflicts (Chan, Luk \& Wang 2005: 464; Ding 1997: 31-45; Kirkbride, Tang \& Westwood 1991: 365-386).

In contrast to these ideas and observations, I argue that traditional Chinese values have been replaced by Western values in A Story of Lala's Promotion and its film adaptation. In the narratives of the novel and the movie about Du Lala's experiences, the operational mechanisms, organisational structures, management concepts and corporate culture of the foreign company are simply transplanted into the Chinese socioeconomic system and cultural milieu. Therefore, the experience of Chinese white-collar workers affiliated to these foreign companies provides a microcosm of the broader Westernisation and globalisation of the world economy and corporate culture. Despite Chinese workers encountering and negotiating both national / local and international / Western values during the transformative process by which a transnational corporate culture is localised, the overwhelming influence of Western corporate culture on Chinese employees is displayed clearly in Lala's story.

Du Lala is in her early twenties and from southern China. Although she has a face and body perceived as above average, she is from a working-class family and has to rely on her wits and hard work to make a living after graduating from university. After working in a state-run enterprise for a year, she finds a sales job with a privately owned company. After four years of continual sexual harassment from her boss, Lala quits. She finds a new position as a sales assistant in a foreign-owned, world top-500 enterprise, DB. As a result of her diligence and intelligence, she is promoted to administrative supervisor after only five years, and then to HR and administration manager. After almost ten years 
of hard work, and still in her late twenties, Lala becomes a member of the newly formed Chinese middle class. Indeed, she appears to be a stereotypical representative of the middle class in contemporary China, having no recognised familial background of note, but having received a good education and overcomes a range of obstacles until she eventually achieves success. For many Chinese people, her story of 'success' is more valuable than that the wealth of Bill Gates (Zhang 2010). ${ }^{2}$

DB, the global, top-500 US communications company where Lala works, is a typical Western enterprise. Both its organisational structure and management strategy represent US-style corporate culture. According to Chan, Luk and Wang, 'Corporate culture refers to the values, beliefs, and principles that serve as a foundation for an organization's management system, and the set of management practices and forms of behaviour that both exemplify and reinforce those basic principles' (2005: 466). At DB, classic Western management ideas, such as STAR (situation, task, action and result) and SMART (specific, measurable, attainable, relevant and time-based), signify the high efficiency, rationalisation and pragmatism of the company's management style. From careful budgeting to painstaking negotiations, and from thorough investigation to results analysis, Lala gradually familiarises herself with Western management concepts and strategies, and eventually becomes highly skilled at them. Shifting from a slow-paced and ineffective working style in the state-run and privately owned Chinese company, to a fast-tempo, efficient and logical Western working approach, Lala transforms herself into an independent, capable and successful female operator at DB's management level. She personifies the influence that globalisation exerts over China, in particular, its influence on young Chinese women and their career trajectories and life experiences.

According to Fan and Regulska, Chinese women's emancipation at both the economic and physical level, as promoted during the Mao era, did not 'necessarily enrich women's identity with the desire for professional success and economic independence' (2008: 93). They add that, 'changes introduced under socialism didn’t eliminate gender discrimination as reflected in wages, occupational attainment and promotion' (2008:

\footnotetext{
${ }^{2}$ Alongside Lala, the main characters in A Story of Lala's Promotion are: Howard-CEO of the Chinese company; Lester - HR director; David - major clients department sales director; Rose - administration manager; Du Lala — HR and administration manager (after Rose leaves the company); Zhou Liang-HR and administration supervisor of the Beijing Department; Pamela-HR and administration supervisor of the Shanghai Department; and, Zhou Jiuyi-HR and administration supervisor of the Shanghai Department (after Pamela leaves).
} 
95); rather, those changes reinforced women's double burden in the workplace and at home. In the post-socialist transition era, when a market economy with Chinese characteristics was implemented by a state with a developmental approach, traditional gender ideology practices in the labour market were resumed and overt gender discrimination when hiring employees was common (Fan 2000: 423-424; Fan 2003: 27; Fan 2004: 284; Fan \& Regulska 2008: 96-100). In the twenty-first century, for example, men still dominate leadership positions, such as heads of government and corporations, managers and senior clerical staff. As Fan has noted, under the rubric of a developmentalist market economy, the Chinese state 'encourages and enables the development of a new capitalist-like labour regime, which in its pursuits of costminimization and profit-maximization fosters segmentation and division of labour' (2003: 24). This has led to explicit gender discrimination in the job market. Given this situation, Western style corporate culture provides opportunities for young aspirational Chinese female workers to develop their skills and knowledge, and to compete equally with their male counterparts in business circles as they move into supervisory and managerial positions in foreign corporations, like Rose, Lala and Pamela in A Story of Lala's Promotion and Go Lala Go!

Other characteristics of the Western business world revealed in the novel and the film are its cruel competitiveness, and employees' widely held awareness of being and working in the midst of continual crisis, or crisis consciousness. Within DB, there is pitiless competition between staff. This is revealed by Lester's defensive relationship with Rose, Rose's (Lala's former boss) defensive relationship with Lala, and Lala's own defensiveness with Zhou Liang and Pamela. For example, Lala's manipulation of Zhou Liang and Pamela follow Lester's instructions to her:

\footnotetext{
I am not saying that we are building a harmonious team and everyone needs to listen to you; what I am trying to explain is how to balance your subordinates. If they are perfectly united, it might be the beginning of a nightmare for you. Never make your subordinates too united and never trust any one of them too much. You should make them compete against each other so that you can control the whole situation. Another point is that when you are training them, you should always do it separately. Remember, you are the only versatile man. (Li Ke 2010: 138)
}

The cruel competitiveness of Western companies stimulates crisis consciousness among the employees. Lala is in constant fear of losing her job with DB, and of new staff outperforming her; she knows that her job in DB has nothing to do with 'an iron rice 
bowl. ${ }^{3}$ To stand out from other staff and attain promotion, Lala works until late at night almost every day and rarely takes any paid annual leave, especially when she is in charge of major projects. In the film version Go Lala Go!, many scenes show Lala eating sandwiches while reading documents or working in the storeroom. To a certain degree, Lala's fear of losing her job reflects the ruthless competition and unstable future for employees that characterises employment within the Western business system as it moves into the Chinese setting (Hou 2010: 25).

Interestingly, the novel also shows David, the big client department sales director, under constant stress - just like Lala. The sales division is the core department of a company like DB, and its success determines the company's future, as well as the destiny of its executives. Thus, competition within this division is ferocious. In addition to its internal struggles, the sales department is involved in tensions with other departments. In one plot - seen in both the novel and the film-Lala is directing an office-renovation project. On the day that the office area must be vacated, David and his staff members refuse to obey the order issued by Lala's administrative department, which leads to a nasty quarrel between David and Lala. At the outset, Lala tries to be reasonable, but David refuses to cooperate. Eventually Lala's stubbornness and resolve shocks David and she wins the argument.

This scenario also reveals the competitive nature of Western corporate culture, manifest here in the way that staff are encouraged, if not compelled, to speak out and communicate with each other, often in direct confrontation and competition. Although David is Chinese, he has long been accustomed to Western office politics. At the beginning of their disagreement, David wants to teach Lala - the newly promoted administration supervisor - a lesson. He tries to intimidate her so that he and his department can win the upper hand. This way, in their future dealings, David hopes that Lala will take notice and behave. However, to David's surprise, Lala has also gained insight into Western business culture and instead of enduring his bullying she speaks up for herself with confidence. Lala's previous experiences in a privately owned Chinese company reveals she only resigned when she could no longer endure her manager's sexual harassment. In addition, when Rose intentionally finds fault with Lala soon after

\footnotetext{
3 'An iron rice bowl' is a Chinese saying that refers to an occupation with guaranteed job security, steady income and benefits.
} 
she (Lala) started working at DB as a sales assistant, Lala says nothing, aside from expressing gratitude to Rose for favouring her with advice. After immersion in the Western business cultural environment for a number of years, Lala too begins to use Western ways of problem solving. Thus, in her fight with David, when Lala - a junior young female administration supervisor-challenges the authority of a senior male sales director, she demonstrates her assimilation into the company's corporate culture. At the same time, her career struggles and successes demonstrate the capacity of contemporary Chinese female workers to gain a sense of rights and achieve a measure of independence and authority in the workplace (Du 2010: 24).

In the novel, another purported distinguishing feature of Western business culture is described as its promotion of fair competition. In Chinese culture, on the other hand, a strict system of seniority, in conjunction with personal connections, often determines whether someone-especially a newcomer-survives in a workplace. In the Chinese workplace, Li Ke suggests, people can survive if they have connections, even if they have no capability for the job. However, her novel shows that the Western business environment is different. In the globalised business world, Chinese white-collar workers like Du Lala appear to operate in a much more independent, impartial environment than they did before China's explicit entry into the global economy in the late 1970s. In the novel, for example, this is demonstrated by the depictions of the environment of equal competition provided by DB and its adoption of the 360-degree performance appraisal to assess staff performance, including senior managers like Howard. The 360-degree performance evaluation is a blind review system that summarises and grades comments about an employee made by their supervisor, colleagues and clients; as such, the results are regarded by proponents of the evaluation as objective and convincing. The open and impartial working environment and performance assessment promoted by Western corporate culture makes it possible, the novel suggests, for Chinese staff, especially female workers like Du Lala, to struggle, compete and succeed in the workplace. This in turn casts Du Lala's case into a classic example of a grassroots female clerk transforming herself into a successful middle-class career woman.

However, despite the novel's depictions of the company's impartial competition and transparent management system, the foreign-invested enterprise is also shown to have its own drawbacks. Aside from its encouragement of competition discussed above, the 
drawbacks include exploitation of employees. For instance, when Lala receives her promotion, her new title does not match her sharply increased workload. Further, she only gains the promotion by negotiating directly with her boss:

\footnotetext{
Boss, the renovation project has been completed successfully. I've also managed all the administrative departments across the country over the past six months, and everything has gone smoothly. As a result, I believe I have the capacity to be an administrative manager. Would there be a promotion opportunity for me? (Li Ke 2010: 59)
}

This speech and Lala's behaviour demonstrate that in a foreign-invested enterprise, taking the initiative and safeguarding the interests one deserves, is likely to enhance a worker's opportunities for success. This is in sharp contrast, the novel implies, to Chinese workplace culture in which a worker needs to adopt a humble manner in order to progress.

In the globalised epoch, foreign-invested enterprises operating in China potentially bring into the Chinese economic and cultural milieu not only advanced management technology and practices, but also a historically specific corporate culture that purports to characterise itself as independent, efficient and impartial. These characteristics, then, can be 'sold' to employees as concrete alternatives to current Chinese business practices. The message is that Chinese white-collar employees of such companies operate in a more rational, independent, diligent and proactive way than staff in traditional companies. A Story of Lala's Promotion and Go Lala Go! both confirm the power of this distinction, and further reveals how Chinese company culture and working practices have been subsumed by global (Western) standards, through the performance and behaviours of Chinese employees like Du Lala and David in foreign enterprises. In addition, the characters act as mediums and catalysts, transferring foreign concepts, manners and corporate cultural expectations to Chinese readers and viewers who may themselves be assimilated into accepting Western corporate standards.

\section{The new female image and the 'Shelved Ladies' phenomenon}

Recently, a number of novels focusing on female white-collar workers, or 'OLs' (Office Ladies), in foreign workplaces have appeared in China. ${ }^{4}$ For women employed by foreign-owned corporations such novels have, to some extent, come to circulate and be read as corporate textbooks and they showcase realistic workplace issues, situations,

\footnotetext{
${ }^{4}$ The English abbreviation of office lady_-'OL'-is widely used in Chinese literary and media texts to refer to middle-class female office clerks in both Chinese and foreign companies.
} 
relationships and difficulties that readers may relate to, and aspire to overcome (Guo 2010: 231; Peng 2010: 50-51). When Zhang Wei, the scriptwriter of the television version of $A$ Story of Lala's Promotion, was collecting materials for her script, she visited many foreign-owned companies in China, she saw numerous young female employees using a red pen to highlight the key sayings of Du Lala in the novel they possessed (Zhang 2010). For those who are interested in the phenomenon, these texts have come to function as cultural 'fast food.' Besides the Du Lala series by Li Ke, other novels with similar themes include: Yige Waiqi Nubailing de Riji (Diary of a WhiteCollar Female Who Works in a Foreign Company, 2008), Niu Xiaomi Waiqi Dapinji (Niu Xiaomi’s Struggle in a Foreign Company, 2009) and Liaobuqi de Xiaozhuli (The Great Little Assistant, 2010). In their portrayal of female Chinese white-collar workers struggling in a foreign environment, these novels also adopt a feminist perspective, one that reflects the changing situation of contemporary Chinese middle-class women.

Bailingliren (white-collar beauty) is a term describing a white-collar Chinese woman working in a joint venture or foreign-owned company, and has been used since the 1978 economic reforms. The phrase implies that the female employees in foreign-owned enterprises are attractive middle-class women. There is a perception among Chinese people that these women are good looking - they are known as 'vases' — earn good salaries and have clerical roles such as receptionists and secretaries. They are employed partly for decoration, and their duties are relatively mundane. The emergence of the $\mathrm{Du}$ Lala-style white-collar women in China provides an alternative to the traditional image of the 'white-collar beauty.' With a face and body perceived as above-average, Lala begins with DB as a sales assistant (a very junior position), but is eventually promoted to HR and administration manager as a result, she claims in the novel, of her intelligence, diligence and endurance. Lala's career trajectory thus challenges the connotations of 'white-collar beauty' in the popular lexicon. The widely accepted understanding is that the 'white-collar beauty' enjoys a less competitive and more leisurely working environment; however, A Story of Lala's Promotion reveals the fierce competition and precarious career prospects of women in foreign-owned companies, and Lala's success therefore serves to transform the image of white-collar females from 'vase' to 'super-girl.' This new image of white-collar women workers stresses the importance of women's career performance in foreign-invested enterprises. This is a particularly important message given that the careers of working women have 
traditionally been circumscribed by male-domination and that women to a large degree remain a marginalised subclass in China. In A Story of Lala's Promotion and Go Lala Go! the customary image of the female worker is given a new, subversive twist. Instead of holding positions such as secretary, receptionist, typist and assistant, many female workers in the novel are now the company's supervisors and managers.

The Du Lala phenomenon, then, provides a metaphor for the cultural and social transformations affecting women in contemporary China. Lala achieves economic independence in her early twenties; by her late twenties, she has become a successful single woman, a 'shelved lady,' in the business world. 'Shelved ladies' is the new phrase in China to denote such single women in their late twenties or early thirties who have a decent job and earn an income high enough to provide financial independence and elicit a measure of social respect (Cao 2010: 56). In addition, shelved ladies are autonomous and free-thinking in matters of love and marriage. Zhang calls the shelved ladies the '3S ladies,' where the three s's stand for 'single,' 'seventies' (born in the 1970s) and 'stuck' (2011: 20). 'Stuck' does not have the negative connotations we might expect as the shelved ladies choose to retain their independence while maintaining high expectations for marriage (Zhang 2007: 8). Ma uses a more aggressive term for the shelved ladies: baigujing, ${ }^{5}$ where bai, gu and jing serve as abbreviations for bailing (white-collar), gugan (backbone) and jingying (elite) (2006: 115). According to Ning (2008: 222), the shelved ladies normally have three 'highs'-high qualifications, high intelligence and high income- - which, with their enhanced ambitions, increases their employment opportunities. Because of these advantages, they also have high standards when choosing a partner, making it more difficult for them to find a spouse.

The well-known Chinese sociologist Li Yinhe (2010) notes that economic autonomy is a principle factor in the rise of the shelved ladies phenomenon. In Du Lala's case, her economic independence is reflected in her capacity to purchase her own housing, and she pays 120,000 RMB deposit for an apartment of 80 square metres, ending her roomrenting life ( $\mathrm{Li} \mathrm{Ke} 2010: 21$ ). When she is promoted as HR and administration manager, Lala earns 230,000 RMB on a yearly basis. Due to their economic independence, the shelved ladies do not need to rely on others (in particular a husband) to afford an

\footnotetext{
${ }^{5}$ Baigujing is the name of a female demon in the sixteenth-century Chinese novel Journey to the West (1980), by the Ming Dynasty writer Wu Chengen. Thus, using the phrase to depict white-collar female workers in contemporary China highlights their ability, agility and intelligence.
} 
affluent life style. As such, they are not in hurry to get married and they will not be submissive in their relationships with men. According to Fan:

In China, Confucianism designates specific roles to individuals based on their gender, social class, and position relative to others; it erects boundaries and defines relations between members of society. Thus, women are subordinate to other male members of the family and are expected to be submissive and to sacrifice their interest to those of man. (Fan cited in Fan \& Regulska 2008: 99)

Moreover, in the post-socialist era characterised by a capitalist market economy promoted by the developmentalist Chinese state, the 'social-cultural traditions rooted in Confucianism, which were constrained during the Maoist period, are once again resurfacing and they further reinforce forces of stratification and division of labour worsening women's situation in the workplace and at home' (Fan 2003: 24).

However, those shelved ladies like Du Lala who work in foreign companies provide an alternative female image that contrasts with socio-cultural expectations of the Confucian good wife and wise mother. The shelved ladies are, to some extent, self-governing individuals. They support themselves and live a middle-class life; they choose to work hard, and they compete with men in the workplace. In Lala's case, she works harder than her male colleagues and supervisors, she argues with them over projects and she competes with them for promotions. And as her lived experiences demonstrate, socalled shelved ladies also adopt a scrupulous attitude towards marriage. Du Lala thus represents the ideal post-1970s and -1980s middle-class Chinese woman for many Chinese readers (Peng 2010: 50-51). As Gong states, this ideal woman is 'young, beautiful, fashionable, virtuous and dutiful, considerate, strong and independent. At home, she should be able to run the automatic washing machine and intelligent microwave; outside, she should be a skilled woman, who drives a car and competes hard in the workplace' (2010: 299).

In the novel, the image of the independent, diligent, righteous and respectable young female epitomised by Du Lala contrasts sharply with that of the 'second wife.' In China 'second wife' is an offensive term applied to women perceived to be lazy, parasitic and indecent, and who willingly or forcibly become mistresses of a private businessman or bureaucrat-entrepreneur. The new rich men of China, who are regarded popularly as 'advanced productive forces and also as corrupt polluters of socialist morality' (Jeffreys 2008: 232), provide living support or promotion opportunities for such women, in 
exchange for their sexual services. In Li Ke's novel, Du Lala is also offered an opportunity to become the mistress of her employer in a privately owned Chinese company. However, she rejects his attempts at seduction and resigns from her job. Coupled with her experiences of frequent sexual harassment in her previous employment, these circumstances provide the impetus for her determination to find a position in a foreign company. According to Lala, 'there is less sexual harassment in foreign enterprises as the bosses are all very busy due to the fast-paced and highefficiency working manner and environment' (Li Ke 2010: 13). Here, Lala's choice consolidates, for her readers, the image of an economically independent and morally virtuous contemporary Chinese woman.

The other two factors contributing to the shelved ladies' phenomenon are career ambition and social recognition. Lala's ambition and her struggle to overcome workplace adversity ensure that her story is full of practical significance for her shelved ladies readers, and for readers who aspire to be shelved ladies (Cao 2010: 56-57). In the film adaptation Go Lala Go! Lala asserts in multiple scenes her own career expectations. In both the movie and the novel, when she and David have an affair, she thinks carefully about the possible consequences of their relationship. Given that DB has strict regulations that prohibit office relationships, Lala decides to intentionally shun David, thereby indicating that she prioritises her career in DB over her love or affection for him.

Here, the role played in the shelved lady narrative of $\mathrm{Xu}$ Jinglei, the director of Go Lala Go!, who enjoys huge career success and fame in China as an actress, director and writer with a large fan base. Xu Jinglei (b. 1974) epitomises the shelved ladies phenomenon. After graduating from the performing department of the Beijing Film Academy, Xu became a successful 'vase' actress. However, to demonstrate that she was capable of more than performing 'vase' roles, she began to write and direct films. Her 2003 film Wo he baba (My Father and I), and her second from 2005, Yige mosheng nuren de laixin (Letter from An Unknown Woman), respectively won the best debut director and best director awards at China's Golden Rooster Film Festival ('Xu Jinglei shi di ershisan jie jinji dianyingjie zuida yingjia' 2003) and Spain's San Sebastian International Film Festival ('Yige mosheng nuren de laixin huo xibanya shengbasidian dianyingjie zuijia daoyanjiang' 2014). Her entries on Old Xu's Blog rank as the top blog among Chinese bloggers ('Lao Xu boke dare de muhou zhenxiang’ 2006). In 2007 
she was invited by the Beijing Film Academy to be a part-time lecturer in the performing arts department. In 2010, just days after the release of Go Lala Go!, the box office income surpassed 100 million RMB, and Xu became the first female director to be a member of the 100 Million Box Office Club in China (Wang 2010: 35). Now approaching 40 years of age, Xu remains unmarried and promotes singlehood (although she has partners). Her life and career experiences mirror the success and confidence of many independent Chinese women, and provide another example of how the shelved ladies phenomenon epitomises contemporary Chinese woman's increasing independence and autonomy. That said, personal and love relationships are significant in the socio-cultural phenomenon, as the film version of Li Ke's novel indicates.

\section{Configuring middle-class identity through consumption}

Go Lala Go! follows the main storyline of Li Ke's novel, but instead of focusing on the operation of the company and office politics, the film is more concerned with the personal and love relationships between the main characters. This emphasis transforms the novel into a Hollywood-style 'romantic comedy.' Another noteworthy trait of the film adaptation is its emphasis on consumerism. In the Chinese socio-cultural lexicon, foreign companies and white-collar beauties automatically connote high incomes, modern skyscrapers, glamour, the middle class, fashion, and luxury lifestyles. Go Lala Go! exploits these rich symbolic meanings and sociocultural and economic connotations to provide selling points of the movie for Chinese viewers.

The framing of Go Lala Go! provides an instructional viewing experience for the audience by mapping out the living and working conditions of the emerging middle class in contemporary China. The film opens with panoramic shots of downtown Beijing's business centre. Sunlight reflects off rows of skyscrapers, giving the city an internationally recognisable metropolitan appearance. Shots of the interior decor of company buildings and offices also confirm a modern, globally recognisable aesthetic. The spacious open-plan working areas, the stylish staff cafes and even the exotic holiday destinations and Western-style celebratory parties on view all gesture toward Western middle-class white-collar employee expectations of employment in a multinational corporation.

More to the point, Go Lala Go! caters to the illusionistic and hedonist logic of a consumer society by seeking to continuously manufacture and promote sensual stimuli 
and emotional outlets for its Chinese audience (Peng 2010: 50). The film's highly criticised product placements add weight to my argument, given the history in China of films that have been popularly critiqued for overt product placement. In 2004, for example, Feng Xiaogang's Tianxiawuzei (A World Without Thieves) was criticised for including too many product placements. However, $A$ World still achieved huge box office success. Based on the enormous appeal of Li Ke's novel to Chinese readers, $\mathrm{Xu}$ Jinglei's film adaptation attracted many companies who wanted to advertise their products in her film. To some extent emulating Feng Xiaogang, Xu Jinglei turned Go Lala Go! into a product placement show. Brands like Lenovo-a Chinese multinational technology company that acquired IBM's personal computer business and Motorola Mobility - Cartier, Mazda, Lipton, Nokia, Dove and Lotto, are favoured and mentioned by the film's characters. These references include white Lenovo desktops, Lipton teabags in the office tearoom, and the Mazda MX5 (a sports car designed for fashionable metropolitan females) seen driving through downtown Beijing. These signify the trendy and luxurious lifestyles of white-collar office clerks in the Chinese capital. The characters' relations or references to these popular brands (most foreign) thus have sociocultural and economic connotations that in turn identify their social status and preferred cultural aesthetics as middle-class white-collar Chinese workers and consumers. With such representations the film shows how Western corporate influences acculturate the collective consumption preferences and lifestyles of the Chinese middleclass.

Also of note is the fact that $\mathrm{Xu}$ Jinglei invited the Hollywood fashion designer Patricia Field, the stylist of the US television series Sex and the City, to design clothing for the characters in Go Lala Go! Field chose clothing from Gucci, Loewe, Roger Vivier, Tod's, Dior, Valentino, Moschino and Bluemarine, and constructed from those designers some seventy outfits for the film's characters. Fifty of them were used in the film, which gave the impression to many viewers that Go Lala Go! had become a film version of a fashion magazine. In one scene, after Lala quarrels with David, she goes shopping and purchases clothing from such international brands as Giorgio Armani, Toga, Dolce and Gabbana, Hermes and Agnona. In the film, the consumption of fashionable, expensive and international, notably Western, luxury brands assists the Chinese middle-class white-collar female worker in constructing a social identity that also confirms her economic independence and confidence. 
In 2008, the Chinese critic Yu Keping made the following observations about the impact of cultural products on Chinese perceptions of self and places in the world:

With the rise of the culture industry, culture is exerting influence in many new areas besides education, including consumption, aesthetics, economy, entertainment, and so forth. Culture not only affects the ideology and value systems of human beings; it also exerts deep influence on their lifestyle, consumption style, manufacturing style, and their social psychology. (2008: 173)

Go Lala Go! would seem to be a cultural product that supports Yu Keping's argument, given the film's focus on the lifestyle and consumption patterns of middle-class Chinese female workers in non-Chinese owned multinational enterprises. The Chinese middle class contributes most of the box-office revenue for the film, and Chinese middle-class taste and culture have come to occupy an influential sociocultural space in the film, and by implication, in contemporary China more broadly. This phenomenon has not been without its critics. Janice $\mathrm{Xu}$, for example, lambasts the tendency of contemporary Chinese publishers and media programmers to bow to superficial middle-class taste. This trend, she argues, occurs in books, films and television programs across China:
[A]lthough almost all Chinese citizens have access to television, more recent consumer programming has become increasingly specialised and upscale, addressing and shaping the growing middle-class market with programs on everything from the latest technological gadgets and foreign travel to art investment. These programs embrace icons of global consumer culture and highlight their symbolic meanings, while acknowledging the middle class's striving for empowerment and self-expression within the sphere of consumption. (Xu 2009: 151)

Increasingly, as Xu notes, contemporary Chinese popular television drama serials and films are focusing on middle-class aspirations. Characters in this media enjoy a comfortable lifestyle, reside in modern housing, dress in fashionable, western clothing, and dine at chic restaurants. Chinese audiences are intended to take their cultural cues from these productions.

In addition to its portrayals of the consumption of international brands and luxury goods, the film benefits from the fact that its celebrity actors also have cosmopolitan origins: Xu Jinglei (starring as Du Lala, based in Beijing); Huang Lixing (starring as David, expatriate Chinese, currently Taiwan based); and Mo Wenwei (starring as Rose and Hong Kong based). For Jungji Peng these actors are internationally renowned in the Chinese-speaking world: Xu for her feminine charm and elegant fashion sense; Huang for his classic collection of suits; Mo for her trendy, ground-breaking white-collar beauty (Peng 2010: 50). As Janice Xu notes, such film star qualities function as 'television advertisements, infomercials, shopping programs, and Hollywood-style 
entertainment programs' that 'bombard Chinese audiences with messages and ideas about consumption ... informing them about the latest trends in the market, and teaching them the skills needed to meet the demands of a modern lifestyle' (2009: 151).

\section{Conclusion}

Alongside the film stars' national reputation as celebrities, the dramatic plot of the film sends a message to audiences of the importance of a middle-class identity, and how that identity should be manifest. Du Lala is a modern Cinderella who emerges from nothing to become a successful career woman. Her experiences illustrate the generic journey to middle class status of millions of Chinese citizens, men and women alike. Yet Li Ke's novel and its film counterpart are also indicative of how struggle is central to the middle-class white-collar woman's existence and reputation in China, where romance, however, is not easily pursued. In Lala's case, her career success finally earns her David's respect and love. In other words, the ultimate message of Li Ke's novel is that middle-class white-collar women have pragmatic and realistic expectations about work and personal life because they can distinguish between what is indispensable and unreliable for them. Romance simply functions as a deserved bonus for their career accomplishments and successes. This aspirational narrative of Go Lala Go! thus reveals many of the emergent characteristics of the so-called 'new' Chinese woman.

The success of the Du Lala series is not accidental. The theme of the novel and filmthe life of white-collar women workers employed by joint ventures and foreign-owned enterprises - is now a recognisable and hugely successful and popular scenario in Chinese popular cultural production. As I have argued in this article, A Story of Lala's Promotion and its film adaptation, Go Lala Go! shed light on the ways in which Western economic and corporate cultural paradigms have gained traction and influence in China since its opening to the capitalist realm in the late 1970s. Indeed, perhaps the most important critical lesson to be drawn from the novel A Story of Lala's Promotion and its film adaptation Go Lala Go!, are their respective contributions to the evolutionary representation of contemporary Chinese white-collar women from their depiction as 'white-collar beauties' to 'super girls' to 'shelved ladies.' 


\section{Reference List}

Albert, M. 2007, ‘Globalization Theory: Yesterday’s Fad or More Lively Than Ever?’ International Political Sociology, vol. 1: 165-182.

Cao Ruixia 2010, 'Du Lala Shengzhiji: Yuzhongbutong de Meili' ('Go Lala Go! A Different Kind of Prettiness'), Dianying Wenxue (Movie Literature), vol. 16: 56-57.

Chan, K.-B., Luk, V. \& Wang, G. X. 2005, 'Conflict and Innovation in International Joint Ventures: Toward a New Sinified Corporate Culture or Alternative Globalization,' China Asia Pacific Business Review, vol. 11, no. 4: 461-482.

Ding, D. Z. 1997, 'Control, Conflict and Performance: A Study of US-Chinese Joint Ventures,' Journal of International Marketing, vol. 5, no. 3: 31-45.

Du Jun 2010, 'Jiedu Dianying Du Lala Shengzhiji de Nuxing Yishi' ('Understanding the Female Sensibility in the Film Go Lala Go!'), Dianying Pingjie (Movie Review), vol. 8: 24-25.

Fan, C. C. 2000, 'Migration and Gender in China,' China Review, (eds) C.-M. Lau \& J. Shen. Chinese University of Hong Kong Press, Hong Kong. 2003, 'Rural-Urban Migration and Gender Division of Labor,' Transitional China International Journal of Urban and Regional Research, vol. 27, no. 1: 24-47. 2004, 'The State, the Migrant Labor Regime, and Maiden Workers,' China Political Geography, vol. 23: 283-305.

Fan, C. C. \& Regulska, J. 2008, 'Gender and The Labor Market in China and Poland,' Urban China in Transition, (ed.) J. R. Logan. Blackwell Publishing, Boston, MA: 89-112.

Feng Xiaogang (dir.) 2004, Tianxiawuzei (A World without Thieves), feature film. China, Huayi Brothers Media Corporation, Hong Kong Media Asia Films Ltd and Beijing Forbidden City Film Co.

Gong Qian 2010, 'Red Women and TV Drama,' Contemporary Chinese Visual Culture: Tradition, Modernity, and Globalization, (ed.) C. Crouch. Cambria Press, New York: 295-315.

Guo, Junsheng 2010, 'Zhichang Xiaoshuo Xuyao Bei Fuyu Sixiang he Wenhua Neihan' (The Career Place Novels Need to Have More Cultural Connotations'), Meili Zhongguo (Charming China), vol. 13: 231-232.

Hou Shuwen 2010, 'Du Lala Shengzhiji: Xiandai Zhichang de Shengcun Tiyan' ('Go Lala Go! Surviving in the Modern Workplace'), Dianying Pingjie (Movie Review), vol. 11: 25-26.

Hong Hulang 2009, Niu Xiaomi Waiqi Dapinji (Niu Xiaomi’s Struggle in a Foreign Company). Jiuzhou Press, Beijing.

Jeffreys, E. 2008, 'Advanced Producers or Moral Polluters? China's Bureaucrat-Entrepreneurs and Sexual Corruption,' The New Rich in China: Future Rulers, Present Lives, (ed.) D. Goodman. Routledge, London: 229-244.

Juewang Canghai 2008, Yige Waiqi Nubailing de Riji (Diary of a White-Collar Female Who Works in a Foreign Company). China Friendship Publishing Corporation, Beijing.

Kirkbride, P. S., Tang, S. F. Y. \& Westwood, R. I. 1991, 'Chinese Conflict Preferences and Negotiation Behaviour: Cultural and Psychological Influences,' Organizational Studies, vol. 12, no. 3: 365386.

'Lao Xu boke dare de muhou zhenxiang' (The Truth Behind Old Xu's Blog as a Cultural Hit) 2006, People's Daily Online, 26 April. Online, available: http://media.people.com.cn/GB/40606/4331298.html [Accessed 9 September 2013].

Li Ke 2010, Du Lala Shengzhiji (A Story of Lala's Promotion), 3rd edition. Xian: Shannxi Normal University Press.

Li Yinhe 2010, 'Shengnu Yu Danshen Langchao' ('Shelved Ladies and Singles' Fashion') 6 July. Online, available: http://blog.sina.com.cn/s/blog_473d53360100jwlf.html [Accessed 8 May 2011].

Loubere, N. 2010, 'Is China Conforming to a Westernized Global Culture? An Assimilation Theory Analysis of Chinese-Western Cultural Relations,' Graduate Journal of Asia-Pacific Studies, vol. 7, no. 1: 70-83.

Lu, S. H. 1996, 'Postmodernity, Popular Culture, and The Intellectual: A Report on Post-Tiananmen China,' Boundary 2, vol. 23, no.2: 139-69.

Ma Xiulan 2006, 'Suowei "Shengnu Shidai"' (The So-Called 'Shelved Ladies' Era), Xiandai Yuwen (Modern Chinese), vol. 12: 115.

Ning Hong 2008, 'Shengnu Xianxiang de Shehuixue Fenxi' (A Sociological Analysis of the 'Shelved Ladies' Phenomenon), Lilun Jie (Theory Horizon), vol. 12: 222-223.

Peng Junyi 2010, 'Cong Yingpian Du Lala Shengzhiji Kandao de' ('Reflecting on Go Lala Go!'), Dazhong Wenyi (Popular Literature and Art), vol. 6: 50-51.

Sex and the City 1998-2004, Television romantic sitcom, USA, HBO.

Wang Yidong 2010, 'Du Lala Shengzhiji: Wuzhi Shidai Xiaozhong Dianying de Fanli' ('Go Lala Go!: 
An Example of a Niche Film in the Era of Materialism'), Dianying Pingjie (Movie Review), vol. 12: $35-36$.

Wu Chengen 1980, Xiyouji (Journey to the West). People's Literature Publishing House, Beijing.

Xiao Yi 2010, Liaobuqi de Xiaozhuli (The Great Little Assistant). Tianjin People's Publishing House, Tianjin.

Xu, J. H. 2009, 'Building a Chinese "Middle Class": Consumer Education and Identity Construction in Television Land,' TV China (eds) Y. Zhu \& C. Berry. Indiana University Press, Bloomington. PP

Xu Jinglei (dir.) 2003, Wo he baba (My Father and I), feature film. China, Asian Union Film and Entertainment and Supreme Concept Cultural Development Co. Ltd. (dir.) 2005, Yige mosheng nuren de laixin (Letter from An Unknown Woman) feature film. China, Asian Union Film and Entertainment, and China Poly Group Corporation. (dir.) 2010, Du Lala Shengzhiji (Go Lala Go!), feature film. China, China Film Group Corporation.

'Xu Jinglei shi di ershisan jie jinji dianyingjie zuida yingjia' (Xu Jinglei is the Biggest Winner at the $23^{\text {rd }}$ Golden Rooster Film Festival) 2003, People's Daily Online, 6 November. Online, available: http://www.people.com.cn/GB/yule/1080/2171948.html. [Accessed 8 September 2013].

'Yige mosheng nuren de laixin huo xibanya shengbasidian dianyingjie zuijia daoyanjiang' (Letter from An Unknown Woman Wins the Best Director Award at Spain's San Sebastian International Film Festival) 2014, Tudou Web, 12 June. Online, available: http://www.tudou.com/programs/view/ZDogOTg9-04/ [Accessed 8 September 2014].

Yu Keping 2008, 'The Developmental Logic of Chinese Culture Under Modernization and Globalization Boundary, vol. 35, no. 2: 157-82.

Zhang Wei 2010, 'Du Lala Re Zheshe Chude Zhongguo Zhongchan Jieji Xianxiang' ('Du Lala Hit Reflects the China Middle-Class Phenomenon'), Asian Weekly, 6 June.

Zhang Yajun 2011, 'Woguo "shengnu” Wenti de Shehuixue Sikao' ('A Sociological Reflection on the “3S Lady” Phenomenon'), Shandong Nuzi Xueyuan Xuebao (Journal of Shangdong Women's University), vol. 96, no. 2: 20-24.

Zhang Yue 2007, 'Xiandai Dushi "Shengnu” Xianxiang de Shihuixue Toushi' ('A Sociological Reflection on the "Shelved Ladies" Phenomenon in Modern Cities'), Shangxi Qingnian Guanli Ganbu Xueyuan Xuebao (Journal of Shanxi College for Youth Administrators), vol. 20, no. 4: 810.

Zhou Xiaohong 2005, Zhongguo Zhongchan Jieji Diaocha (An Investigation of China's Middle Class). Social Science Archive Press, Beijing. 